\title{
Penerapan Model Waterfall pada Sistem Informasi Akuntansi Pembayaran Upah Buruh Sadap Getah
}

\author{
L S Ramdhani ${ }^{1}$, A Luthfiyani ${ }^{2}$, Y Afriani ${ }^{3}$ \\ Sistem Informasi, Universitas Bina Sarana Informatika ${ }^{1}$, \\ Sistem Informasi Akuntansi, Universitas Bina Sarana Informatika ${ }^{23}$ \\ Jl. Cemerlang No. 8 Sukakarya, Sukabumi, 43135, Indonesia ${ }^{123}$ \\ email: lis.lud@ bsi.ac.id*1, anggitaluthfiyani20@gmail.com ${ }^{2}$, yuliafriani321@gmail.com ${ }^{3}$ \\ diterima: 1 Januari 2020 \\ direvisi: 9 April 2020 \\ dipublikasi: 1 September 2020
}

\begin{abstract}
Abstrak
Sadap getah merupakan kegiatan memperoleh getah dengan teknik sayatan $1 / 2$ spiral dari kiri atas ke kanan bawah. Kegiatan ini menjadi salah satu pilihan mata pencaharian masyarakat Indonesia karena Indonesia merupakan negara penghasil getah peringkat kedua di dunia. Perum Perhutani Divisi Regional Jawa Barat dan Banten merupakan unit kerja yang mengelola hutan dan mengelola pembayaran upah sadap getah. Sistem pembayaran upah yang digunakan Perum Perhutani masih dilakukan dengan cara konvensional yaitu mencatat daftar hadir, hasil panen, dan untuk laporan masih dilakukan dengan cara merekap data yang ada di catatan yang terdahulu sehingga memungkinkan pada saat proses berlangsung terjadi kesalahan dalam pencatatan dan laporan menjadi kurang akurat. Untuk itu dibutuhkan sebuah sistem yang mendukung pembayaran upah buruh sadap getah yang dapat memudahkan dalam sistem pembayaran. Maka pada penelitian ini akan dibangun sebuah sistem pembayaran upah sadap getah berbasis web dengan menerapkan model waterfall sehingga menjadi solusi dari permasalahan tersebut dan dapat memberikan kemudahan terhadap pelayanan sistem pembayatan upah sadap getah.
\end{abstract}

Kata kunci: Sistem Informasi; Waterfall; Pembayaran Upah; Sadap Getah; Web

\begin{abstract}
Sap tapping is an activity of obtaining sap with the $1 / 2$ spiral incision technique from top left to bottom right. This activity became one of the choices for the livelihoods of the Indonesian people because Indonesia is the second-largest sap-producing country in the world. Perum Perhutani Regional Division of West Java and Banten is a work unit that manages forests and manages wage payments. The wage payment system used by Perhutani Corporation is still carried out conventionally by recording attendance lists, crop yields, and for reports still carried out by recapitating the data in the previous record so that it is possible that during the process an error occurs in recording and the report becomes less accurate. For that we need a system that supports the payment of labor wages and sap that can facilitate the payment system. So in this study a web-based latex tapping payment system will be built by applying the waterfall model so that it becomes a solution to the problem and can provide convenience to the service of the tapping wage payment system.
\end{abstract}

Keywords: Information Systems; Waterfall; Payment of wages; Tapping Gum; Web

\section{Pendahuluan}

Indonesia merupakan negara yang memiliki area perkebunan terluas di dunia, salah satu perkebunannya terdiri dari perkebunan karet dan perkebunan pinus. Dari perkebunan tersebut menghasilkan getah yang biasanya di ekspor atau untuk memenuhi kebutuhan dalam negeri sebagai bahan baku keperluan industri [1]. Sadap getah merupakan proses sayatan 1/2 spiral dari kiri atas ke kanan bawah pada pohon sehingga menghasilkan getah [2]. Kegiatan sadap tersebut dilakukan oleh buruh sadap yang bekerja di Perum Perhutani.

Perum Perhutani Divisi IV Regional Jawa Barat dan Banten menerapkan sistem pembayaran upah untuk buruh sadap getah secara konvensional. Sistem konvensional ini 
yang mengakibatkan kesulitan dalam hal pencarian data-data yang berhubungan dengan pembayaran upah karena data masih disimpan dalam bentuk arsip [3] seperti data perhitungan tarif upah, jenis getah, lokasi, jumlah uang harus disiapkan dan lain-lain. Hal ini membuat sistem pembayaran upah terhadap buruh menjadi kurang efektif dan kurang terawasi secara baik.

Berdasarkan penelitian sebelumnya oleh Bayu Sadewo dan Hendri Irawan [4], sistem informasi pembayaran upah berbasis desktop dapat membantu dalam mempermudah pencarian data lebih cepat serta akurat dan dapat menyimpan data pembayaran dengan baik. Menurut Randy Richi Wuaya Jermias [5] dengan adanya sistem informasi akuntansi gaji dan upah dapat menghemat waktu yang diperlukan untuk pembuatan berbagai macam laporan dan laporan rekapitulasi dana secara cepat dan tepat. Informasi data yang disajikan menjadi lebih akurat dan tingkat ketelitian lebih tinggi sehingga kemungkinan membuat kesalahan sangatlah kecil dan koreksi data dapat dilakukan sewaktu-waktu dan dilaksanakan dengan cepat dan mudah.

Tujuan dari penelitian ini adalah untuk menganalisis sistem pembayaran upah yang sedang berjalan di Perum Perhutani Divisi IV Regional Jawa Barat dan Banten, berdasarkan hasil analisis dilakukan perancangan sistem pembayaran upah di Perum Perhutani Divisi IV Regional Jawa Barat dan Banten berbasis web. Metode yang digunakan untuk mengumpulkan data adalah observasi dan wawancara, sedangkan metode pengembangan sistemnya menggunakan metode waterfall. Manfaat dari penelitian ini adalah menyediakan suatu sistem informasi pembayaran upah sadap getah yang dapat membantu Perum Perhutani Divisi IV Regional Jawa Barat dan Banten dalam hal pendapatan getah sadap, pembayaran upah sadap, pembuatan laporan pembayaran dan pendapatan sadap getah. Sehingga menghasilkan laporan yang lebih informatif dan berkualitas.

\subsection{Pengertian Sistem}

\section{Kajian Pustaka}

Sistem adalah suatu kumpulan atau kelompok dari elemen atau komponen yang saling berhubungan atau saling berinteraksi dan saling bergantung satu sama lain untuk mencapai tujuan tertentu [6].

\subsection{Pengertian Sistem Informasi Akuntansi}

Sistem Informasi Akuntansi adalah sistem yang mengumpulkan dan memproses transaksi-transaksi data dan menyampaikan informasi keuangan kepada pihak-pihak tertentu [7].

\subsection{Pengertian Sistem Informasi Akuntansi Pembayaran Upah}

Sistem Informasi Akuntansi Pembayaran Upah adalan sistem yang memproses transaksi keuangan yang menangani transaksi perhitungan gaji dan upah karyawan dan pembayarannya [8].

\subsection{Model Waterfall}

Model Waterfall adalah model pengembangan sistem informasi yang sistematik dan sekuensial dalam membangun software [9]. Nama model ini sebenarnya adalah Linear Sequential Model. Model ini sering disebut juga dengan Classic Life Cycle atau metode Waterfall [10].

\subsection{Unified Modelling Language (UML)}


Unified Modeling Language (UML) adalah bahasa pemodelan untuk sistem atau perangkat lunak yang berparadigma berorientasi objek [11]. Pemodelan (modelling) sesungguhnya digunakan untuk penyederhanaan permasalahan-permasalahan yang kompleks sedemikian rupa sehingga lebih mudah dipelajari dan dipahami. Beberapa diagram yang sering digunakan yaitu, use case diagram, activity diagram, sequence diagram, dan class diagram.

\section{Metode Penelitian}

Metode yang digunakan dalam penelitian ini yaitu metode pengumpulan data dan metode pengembangan sistem perangkat lunak.

\subsection{Metode Pengumpulan Data}

Untuk menganalisis data dibutuhkan data sistem berjalan pembayaran upah buruh getah yang terdiri dari data penghasilan pendapatan sadap getah dan bukti penerimaan penghasilan, sedangkan teknik pengumpulan data yang digunakan yaitu dengan mengumpulkan data yang didapat dari wawancara (interview) dengan staf buruh dan Karyawan Perum Perhutani Divisi IV Regional Jawa Barat dan Banten. Dan melakukan pengamatan secara langsung (observasi) mengenai tata cara pembayaran upah buruh Perum Perhutani Divisi IV Regional Jawa Barat dan Banten.

\subsection{Metode Pengembangan Perangkat Lunak}

Penelitian ini menggunakan metode pengembangan sistem waterfall. Dengan tahapan sebagai berikut:

a. Analisis Kebutuhan Perangkat Lunak

Proses Pengumpulan kebutuhan, menspesifikasikan kebutuhan perangkat lunak agar mudah dipahami oleh user. Pada tahap ini dilakukan analisis terhadap sistem pembayaran upah buruh sadap getah yang sedang berjalan di Perum Perhutani Divisi IV Regional Jawa Barat dan Banten, dengan mengumpulkan data-data pembayaran upah seperti data buruh, data penghasilan sadap getah, data pembayaran, dan laporan yang berkaitan dengan pembayaran upah buruh sadap getah.

b. Desain

Desain Perangkat Lunak adalah proses multi langkah yang focus kepada desain pembuatan program perangkat lunak termasuk Struktur Data, Arsitektur perangkat lunak, representasi antar muka, dan prosedur pengkodean. Pada tahap desain dilakukan desain sistem dengan menggunakan UML dan desain basis data dengan menggunakan ERD dan LRS.

c. Pembuatan Kode Program (Coding)

Desain harus ditranslasikan ke dalam program Perangkat Lunak. Untuk Pembuatan kode program menggunakan bahasa pemrograman php dan databasenya menggunakan MySql.

d. Pengujian

Pengujian Fokus kepada Perangkat Lunak secara Logic dan Fungsional, memastikan bahwa semua bagian sudah diuji untuk meminimalisir error dan keluaran harus sesuai. Pada pengujian sistem informasi iuran rukun kematian menggunakan blackbox testing.

e. Pendukung (Support) dan Pemeliharaan

Tahap pendukung atau pemeliharaan dapat mengulangi proses pengembangan mulai dari analisis spesifikasi untuk perubahan perangkat lunak yang sudah ada tapi tidak untuk membuat perangkat baru. 


\subsection{Perancangan Sistem}

\section{Hasil dan Pembahasan}

Perancangan sistem informasi akuntansi pembayaran upah sadap getah berbasis web ini dibuat untuk menggambarkan perancangan sistem yang diusulkan mulai dari halaman penghasilan sadap getah dan pembayaran upah sadap getah, jurnal umum, akun, jenis getah, pegawai dan pengguna.

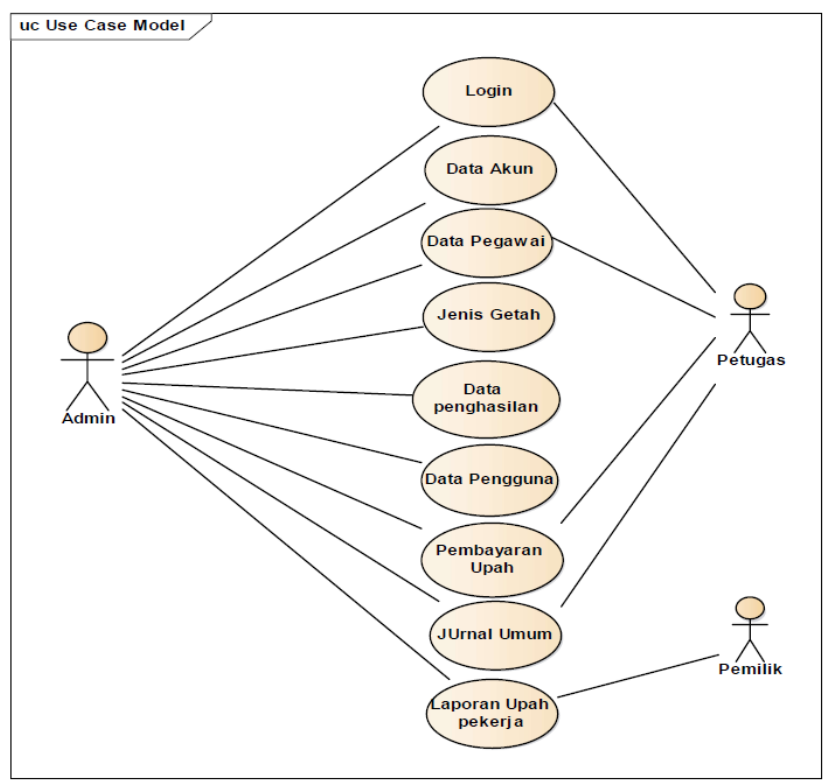

Gambar 1. Use Case Diagram Sistem Informasi Akuntansi

Gambar 1 menggambarkan fasilitas atau menu-menu yang ada di sistem pembayaran upah getah. Yang dapat mengakses hanya tiga pengguna yaitu admin, petugas dan pemilik. Dalam mengakses sistem pembayaran upah getah semua aktor harus melakukan login terlebih dahulu di menu login, terkecuali pemilik. Namun pemilik hanya dapat mengakses laporan upah pekerja. Untuk petugas setelah login dapat mengakses dan mengelola data pegawai, jika ada pegawai baru atau akan meng-update data pegawai bisa dilakukan di menu pegawai. Selain itu petugas dapat memasukan data pembayaran upah pegawai di menu pembayaran upah, dan petugas dapat mencetak kwitansi pembayaran untuk setiap pegawai. Dan setelah melakukan pembayaran kepada pegawai, petugas dapat menginput jurnal umum untuk keperluan laporan keuangan. Sedangkan admin dapat mengakses dan mengelola semua menu yang ada di sistem yaitu mengelola data akun, data pegawai, data jenis getah, data penghasilan, data pengguna, data pembayaran upah, jurnal umum dan laporan upah pekerja.

Gambar 2 menggambarkan aktivitas dari menu pembayaran upah, yang dapat dilakukan di menu pembayaran upah yang dimulai dari petugas mengklik menu pembayaran upah, kemudian sistem akan menampilkan form pembayaran upah. Jika petugas akan menambahkan pembayaran upah maka petugas mengklik tambah data lalu petugas mengisi data pembayaran upah sadap getah dengan isi nama pekerja, tanggal dan jumlah atau hasil sadap. Jika data sudah benar maka tinggal pilih simpan data pembayaran dan cetak kwitansi pembayaran. Jika data isian pembayaran upah belum benar maka pilih batal untuk membatalkan data yang diisikan. Kemudian jika petugas akan mencari data maka pilih cari data dan masukan data yang akan dicari, jika datanya ada maka sistem akan menampilkan data yang dicari. Dan jika petugas akan mengedit data pembayaran, maka pilih edit data pembayaran, kemudian edit data yang akan diubah kemudian simpan. 


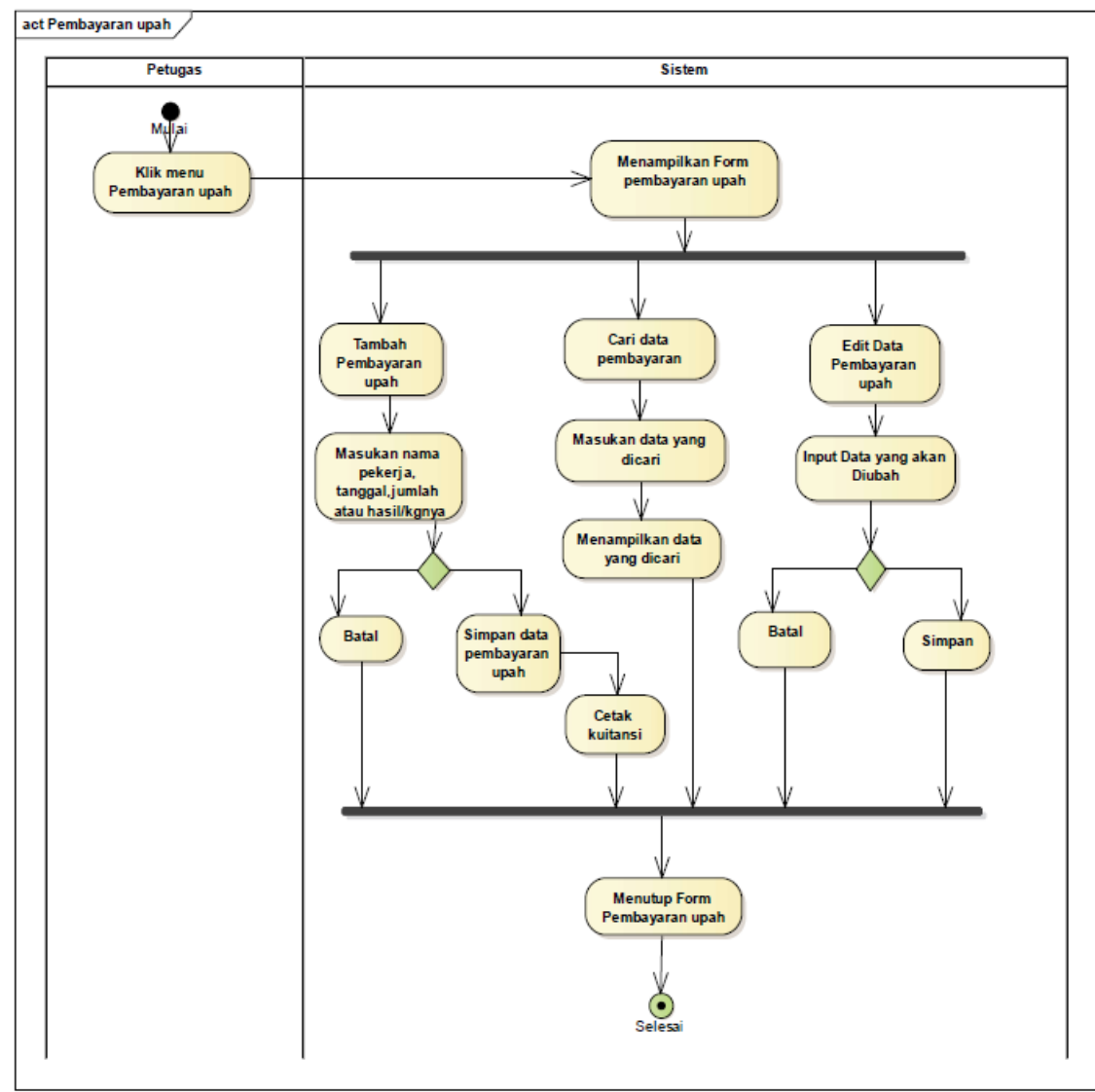

Gambar 2. Activity Diagram Pembayaran Upah

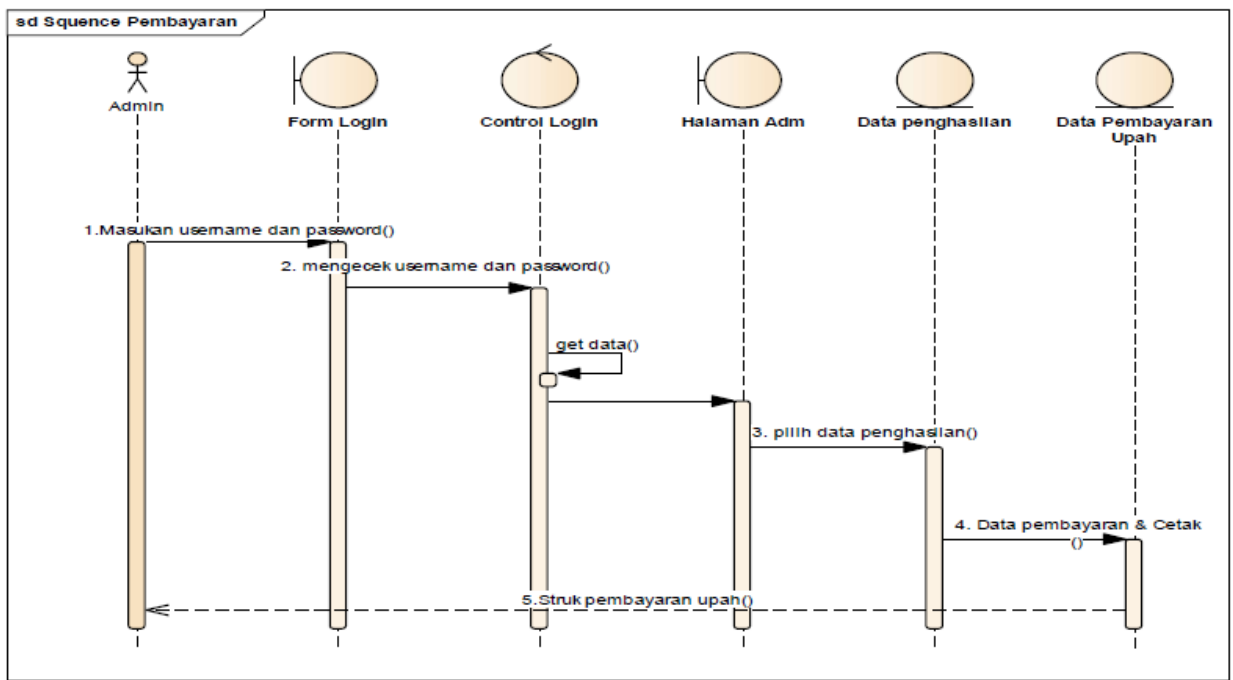

Gambar 3. Sequence Diagram Pembayaran Upah

Gambar 3 menggambarkan aktivitas admin dalam berinteraksi dengan sistem. Admin melakukan login dengan membuka form login dan memasukkan username dan password, kemudian sistem akan mengecek username dan password. Setelah valid maka langsung masuk ke halaman admin kemudian admin memilih menu data penghasilan dan menginput data penghasilan sesuai penghasilan yang didapat petugas sadap getah, lalu petugas dapat membuka form pembayaran dan menginputkan data pembayaran kemudian menyimpan ke file pembayaran, lalu petugas mencetak kwitansi untuk diberikan ke pegawai. 


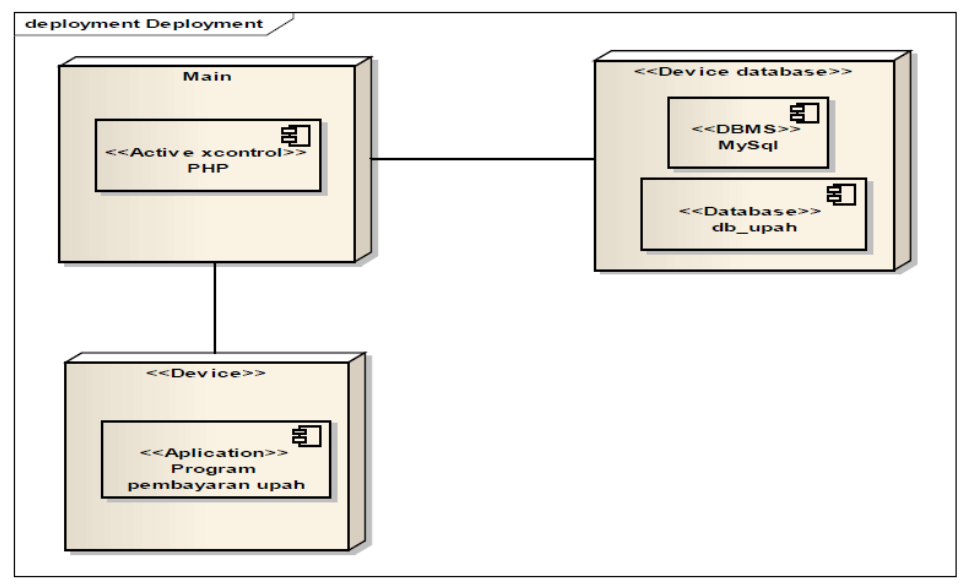

Gambar 4. Deployment Diagram Sistem Informasi Akuntansi Pembayaran Upah

Gambar 4 menggambarkan aplikasi yang dibangun yaitu Program Pembayaran upah, aplikasi ini dibuat menggunakan Bahasa pemrograman PHP dan menggunakan database servernya yaitu Mysql dan untuk database yang digunakan pada aplikasi pembayaran upah ini yaitu db_upah.

\subsection{Desain Database}

1) Entity Relationship Diagram (ERD)

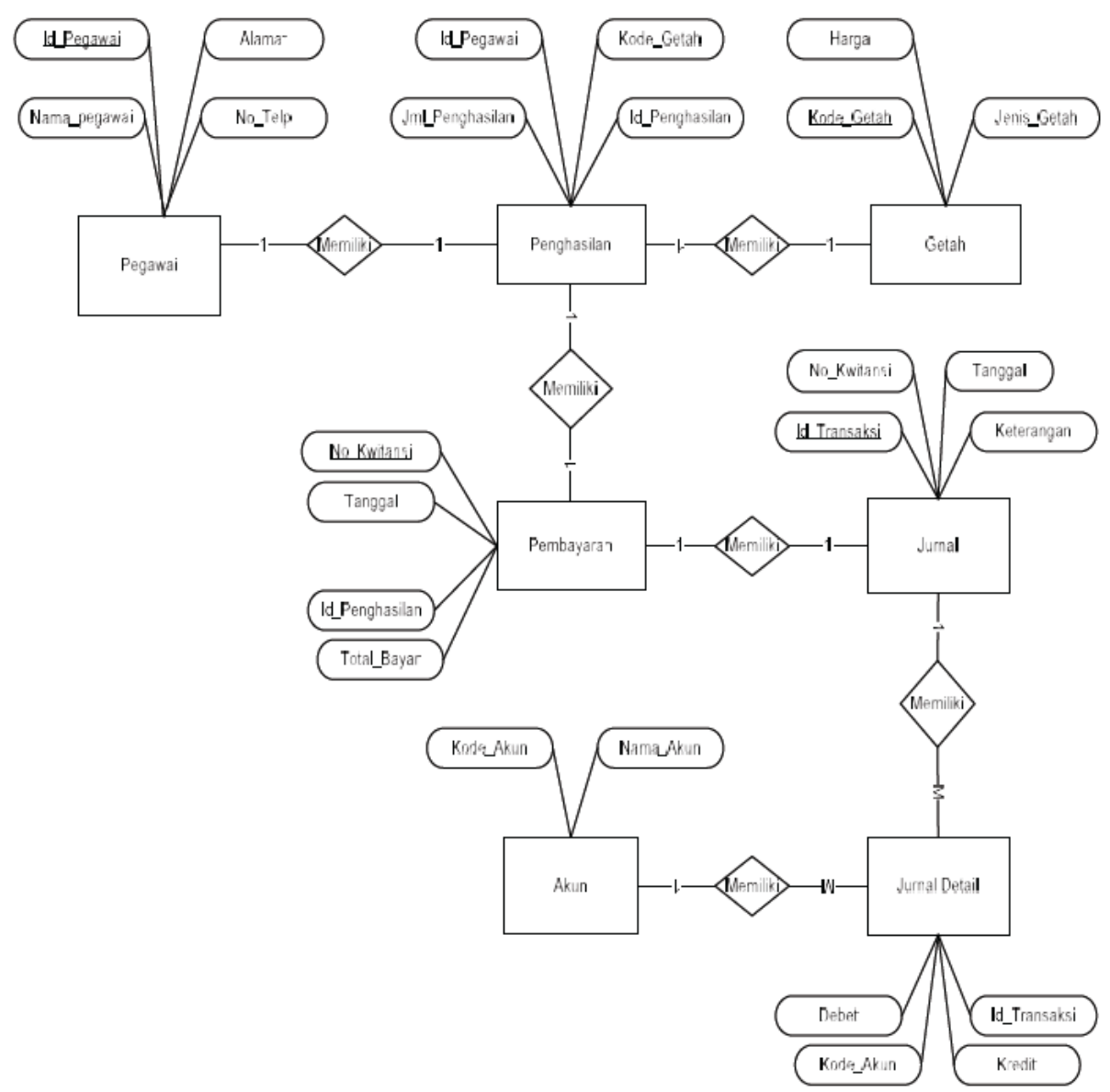

Gambar 5. ERD Sistem Informasi Akuntansi Pembayaran Upah 
Gambar 5 menggambarkan Sistem Informasi Akuntansi Pembayaran Upah dibangun berdasarkan 7 entitas yaitu entitas pegawai, penghasilan, getah, pembayaran, jurnal, detail jurnal dan akun. Ketujuh entitas tersebut memiliki atribut masing-masing, untuk entitas pegawai atributnya terdiri dari id_pegawai, nama_pegawai, alamat, dan no_telp. Untuk entitas penghasilan terdiri dari id_pegawai, kode_getah, jml_penghasilan, dan id_penghasilan. Untuk entitas getah terdiri dari kode_getah, jenis_getah dan harga. Untuk entitas pembayaran terdiri dari no_kwitansi, tanggal, id_penghasilan, dan total_bayar. Untuk entitas jurnal terdiri dari id_transaksi, tangal, keterangan dan no_kwitansi. Untuk detailjurnla terdiri dari id_transaksi, debet, kredit, kode_akun. Dan terakhir untuk entitas akun terdiri dari kode_akun dan nama_akun.

Dari ketujuh entitas memiliki hubungan atau relasi dari entitas satu dengan entitas lainnya. Seperti yang digambarkan diatas bisa dilihat bahwa entitas petugas entitas getah dan memiliki relasi one to one terhadap entitas penghasilan, kemudian entitas penghasilan memiliki relasi one to one terhadap entitas pembayaran, kemudian entitas pembayaran memiliki hubungan one to one terhadap entitas jurnal. Kemudian entitas jurnal memiliki hubungan one to many terhadap entitas detail_jurnal, dan entitas detail_jurnal memiliki hubungan one to many terhadap entitas akun.

\section{2) Logical Record Diagram (LRS)}

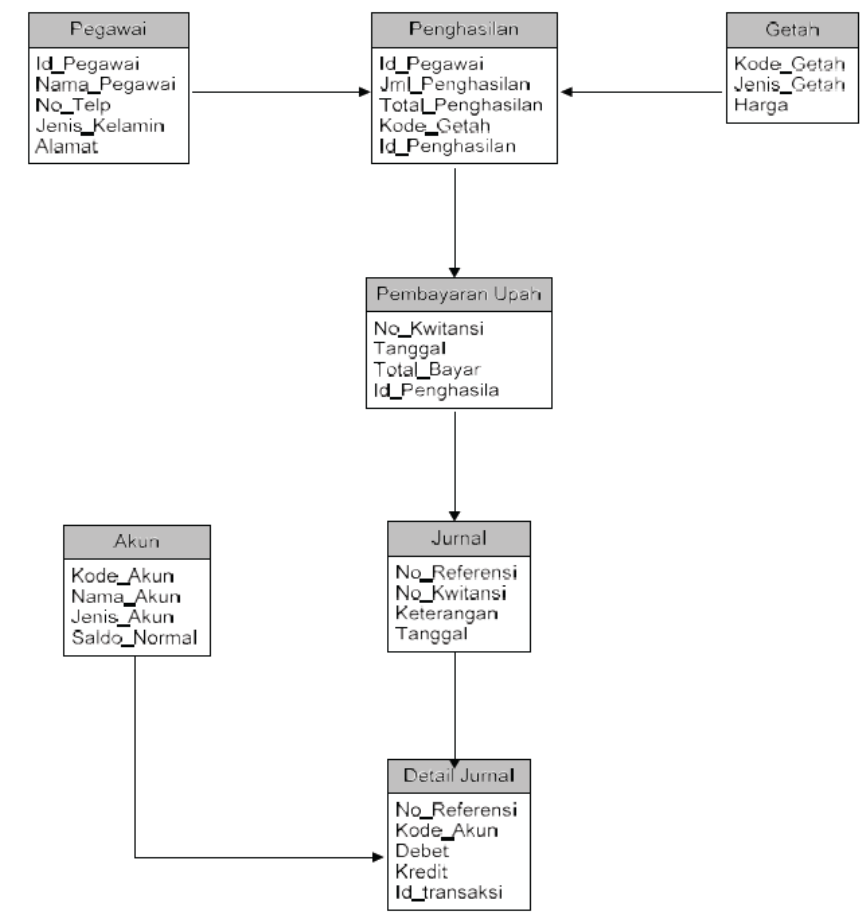

Gambar 6. LRS Sistem Informasi Akuntansi Pembayaran Upah

Gambar 6 menggambarkan LRS yang dibangun pada sistem informasi pembayaran upah sadap getah. LRS di dapat dari pengolahan ERD, dari tujuh entitas yang dipakai di ERD kemudian di transformasikan ke dalam bentuk tabel maka didapat tujuh tabel yang akan digunakan dalam membangun aplikasi sistem informasi pembayaran upah yaitu tabel pegawai, tabel getah, tabel penghasilan, tabel pembayaran, tabel jurnal, tabel detail jurnal dan tabel akun. Kemudian untuk atribut akan ditransformasikan menjadi field untuk membangun tabel, sedangkan relasi tiap tabel masih sama dengan ERD. 


\subsection{Usef Interface}

Berikut ini merupakan tampilan antarmuka dari sistem informasi akuntansi pembayaran upah sadap getah berbasis web yang dirancang untuk diterapkan pada Perum Perhutani Divisi IV Regional Jawa Barat dan Banten:

\section{SISTEM INFORMASI AKUNTANSI PEMBAYARAN UPAH BURUH SADAP GETAH}

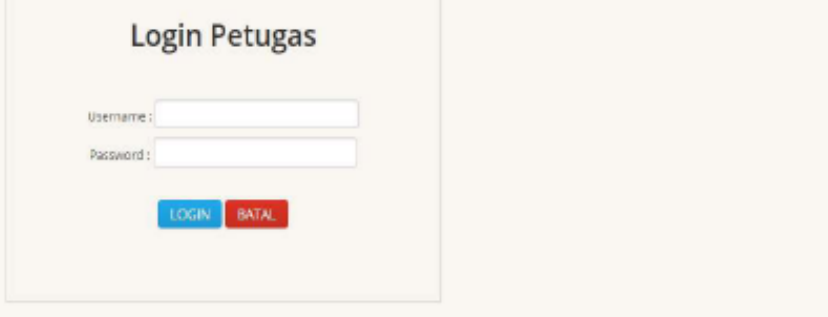

Gambar 7. Halaman Login

Gambar 7 merupakan halaman form login dan buton untuk membuka halaman dashboard sistem informasi akuntansi pembayaran upah.

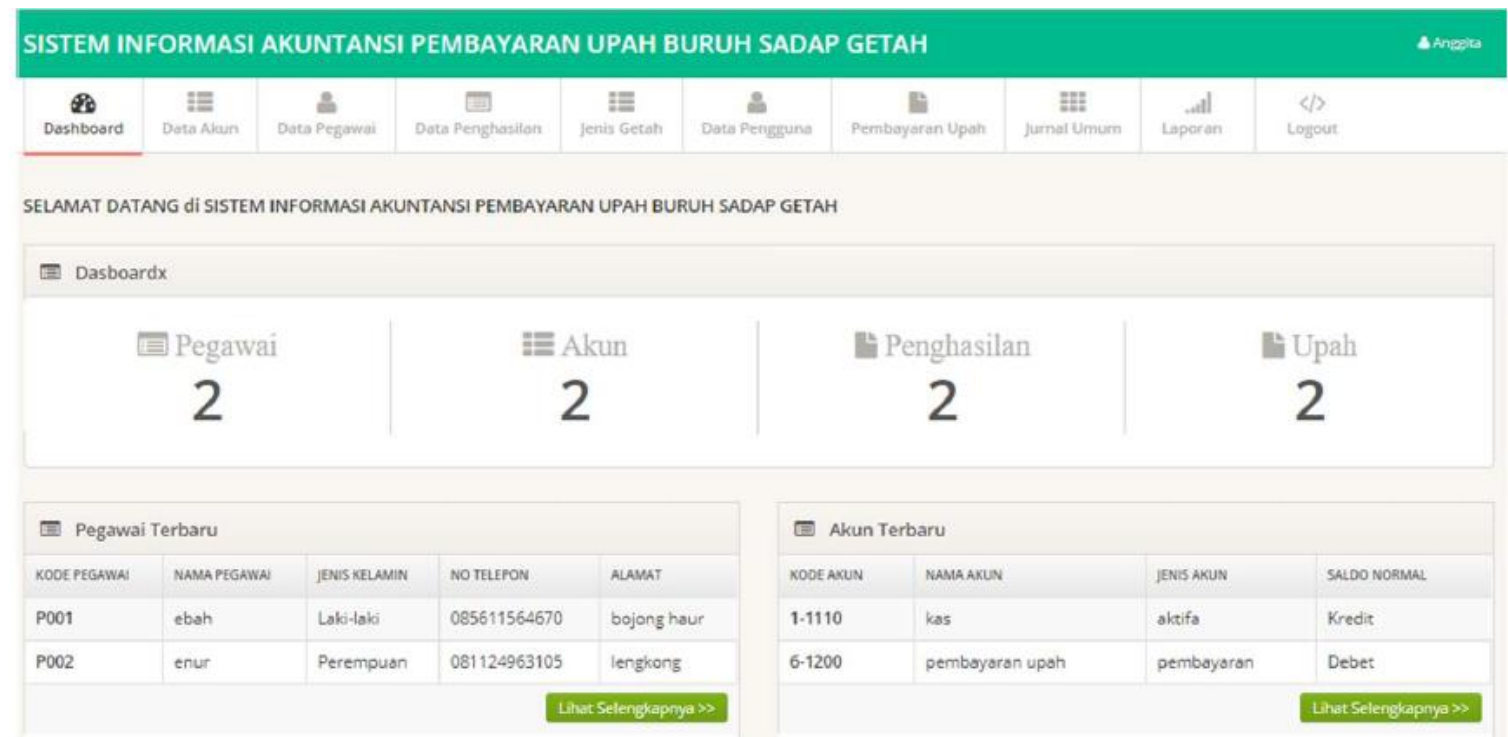

Gambar 8. Halaman Dashboard

Gambar 8 merupakan halaman dashboard dimana pada halaman tersebut terdapat beberapa menu yaitu, menu dashboard, data akun, data pegawai, data penghasilan, jenis getah, pembayaran upah, jurnal umum dan laporan. 


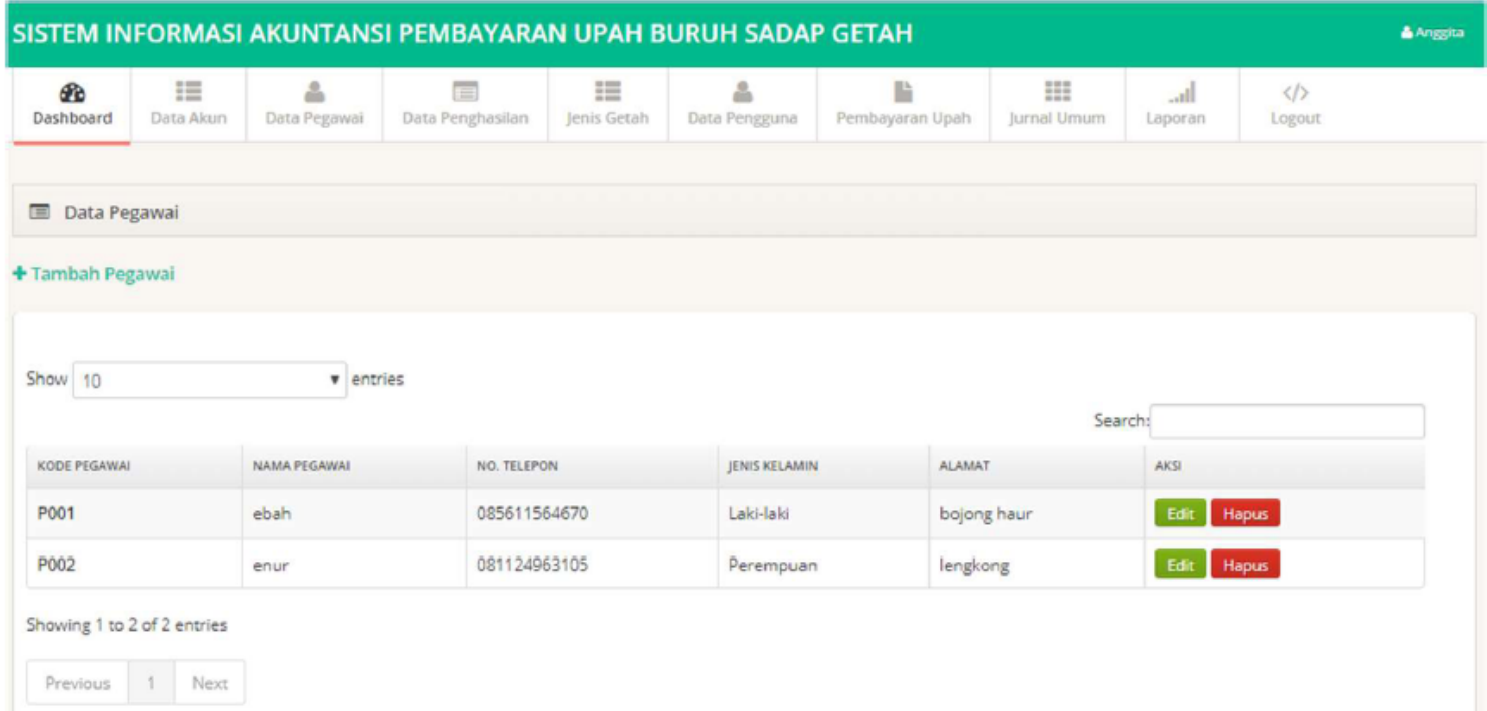

Gambar 9. Halaman Data Pegawai

Gambar 9 merupakan halaman data pegawai, halaman ini berfungsi untuk menambah data pegawai atau buruh baru, mengedit data pegawai atau buruh, ataupun menghapus data pegawai atau buruh.

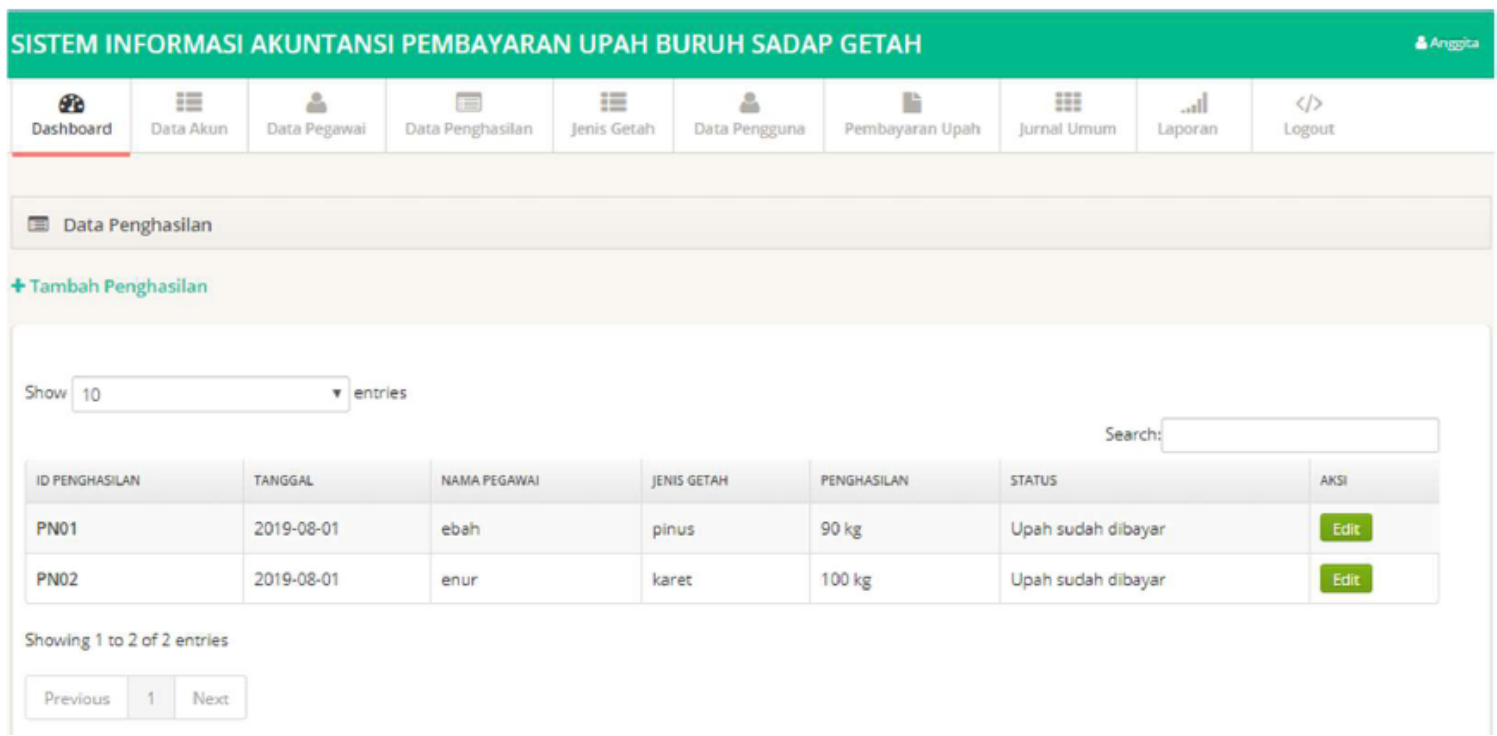

Gambar 10. Halaman Data Penghasilan Sadap Getah

Gambar 10 merupakan halaman data penghasilan, halaman ini digunakan untuk menginput penghasilan atau pendapatan sadap getah yang diperoleh oleh buruh, atau mengedit pendapatan sadap getah buruh. Dan dapat melihat status pembayaran upah buruh. 


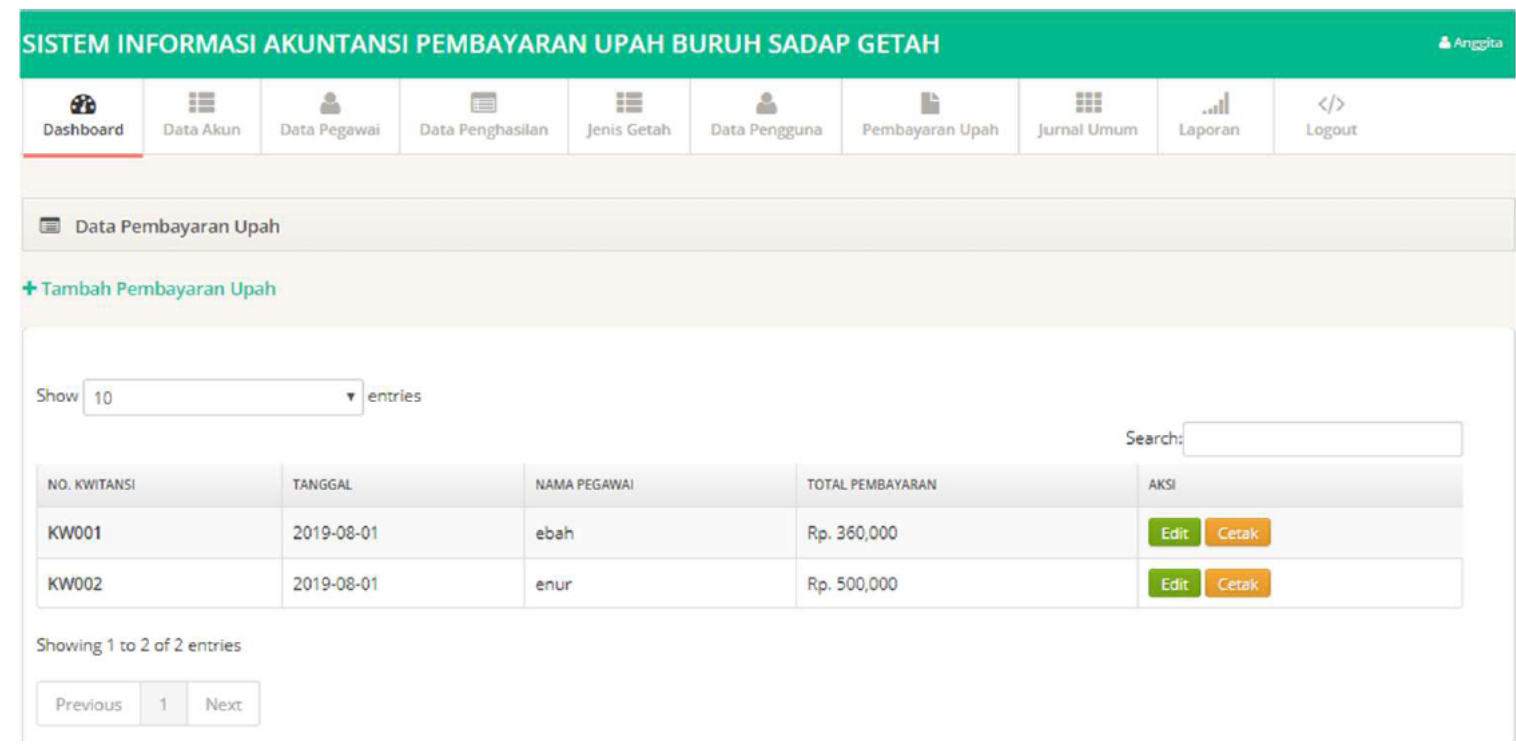

Gambar 11. Halaman Pembayaran Upah Sadap Getah

Gambar 11 merupakan halaman pembayaran upah digunakan menambah pembayaran upah yang diambil dari data penghasilan, kemudian petugas menyimpan data tersebut dan mencetak bukti upah pembayaran buruh sadap getah untuk diberikan kepada buruh. Selain itu petugas dapat mengedit data pembayaran jika ada kekeliruan.

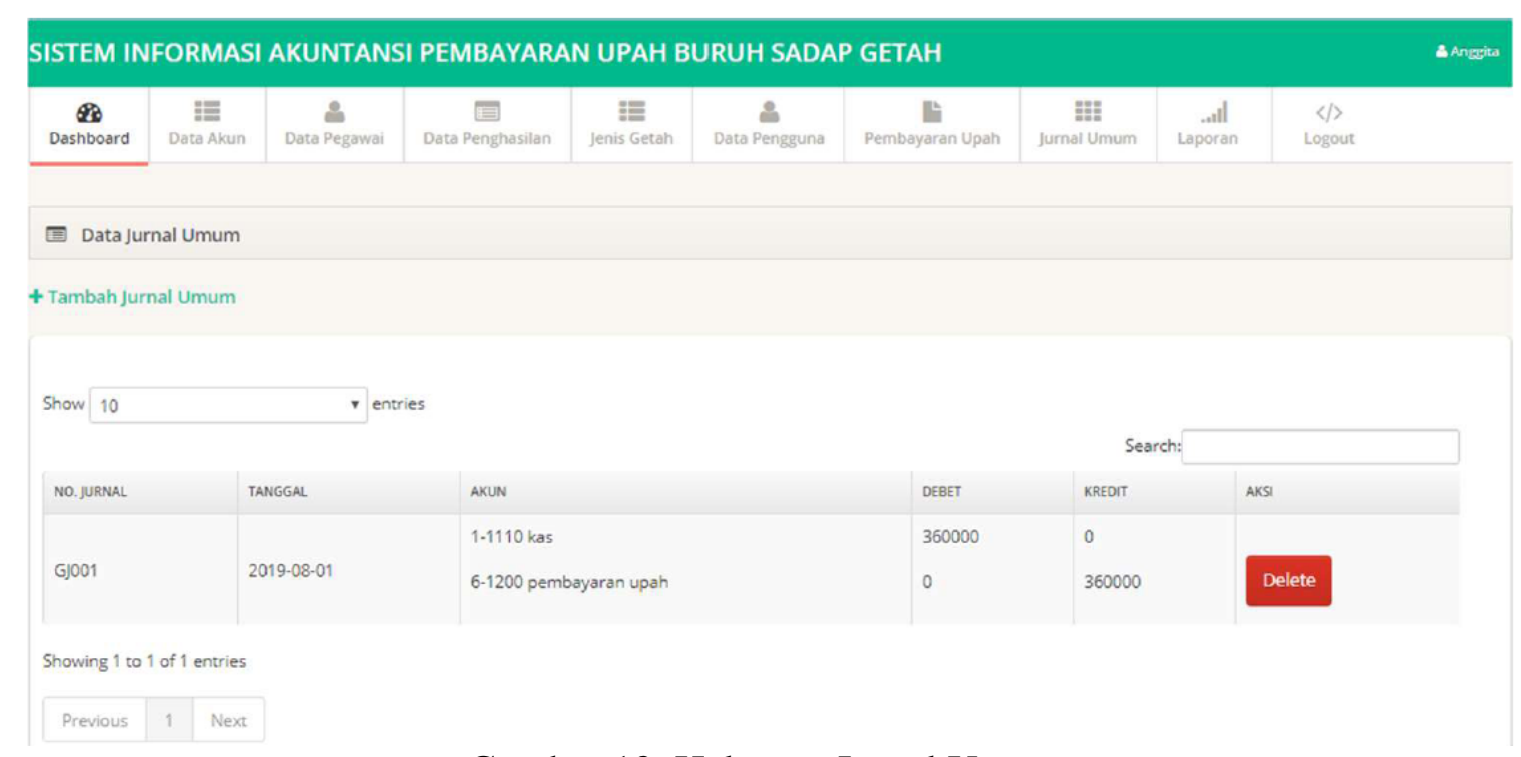

Gambar 12. Halaman Jurnal Umum

Gambar 12 merupakan halaman jurnal umum, digunakan untuk menyimpan data pengeluaran uang. Di halaman tersebut dapat menambah data dan menghapus data jurnal umum. 


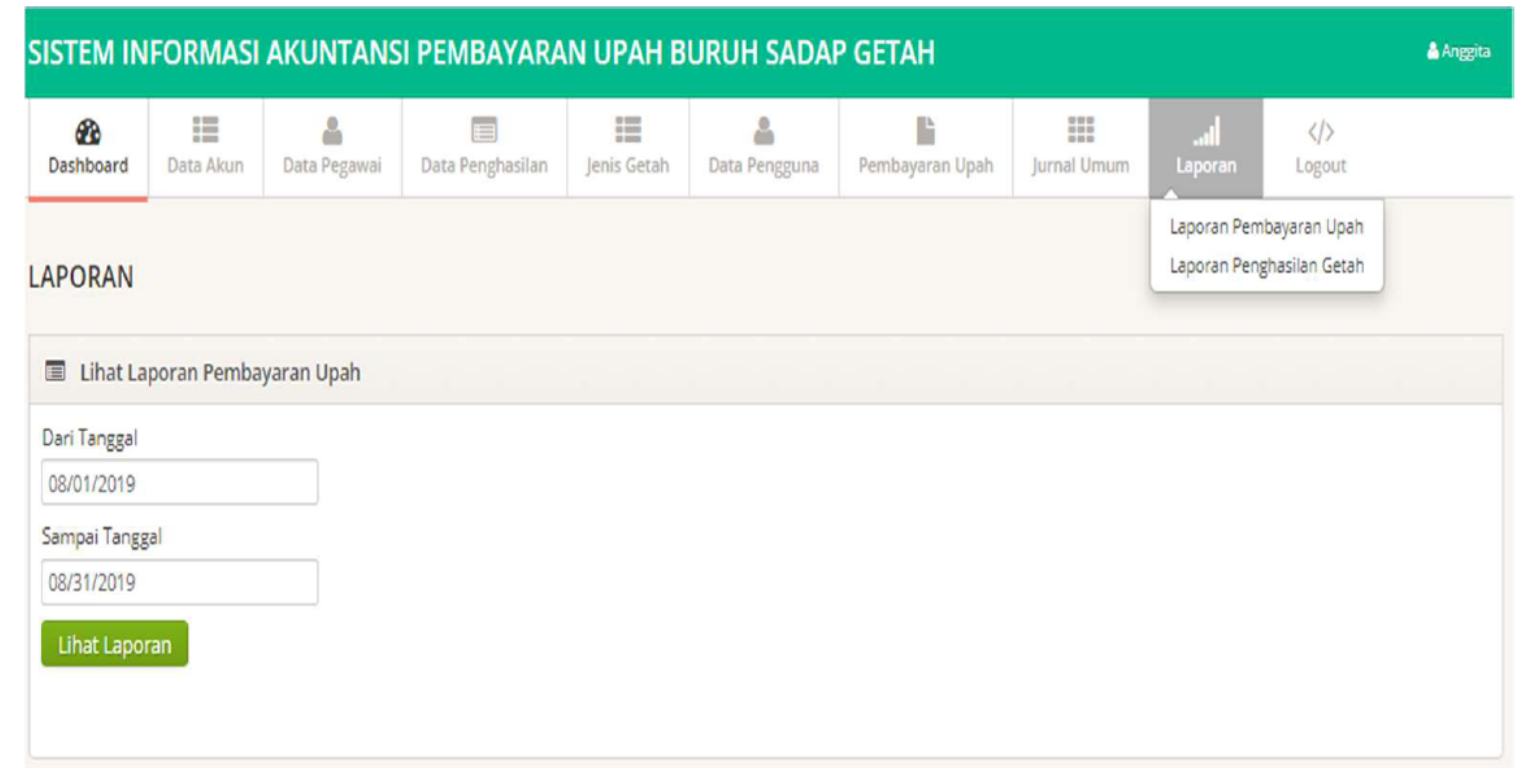

Gambar 13. Halaman Cetak Laporan

Gambar 13 merupakan halaman cetak laporan, halaman ini dapat memfilter tanggal sesuai kebutuhan yang diinginkan.

\section{Kesimpulan}

Berdasarkan penelitian dan pembahasan yang telah dilakukan, maka dapat ditarik kesimpulan bahwa dengan menerapkan model waterfall pada sistem informasi akuntansi pembayaran upah sadap getah berbasis web dapat membantu meringankan serta mempercepat proses kerja pembayaran upah buruh sadap getah, sehingga dapat menghemat waktu dan tenaga petugas pembayaran upah buruh. Selain itu juga dapat menghasilkan laporan pembayaran upah buruh sadap yang baik, akurat, dan lebih informatif. Saran dari penulis karena perkembangan teknologi akan semakin berkembang maka, untuk selanjutnya dapat membuat aplikasi pembayaran upah Buruh sadap getah berbasis Android.

\section{Daftar Pustaka}

[1] D. Pusari and S. Haryanti, "Pemanenan Getah Karet (Hevea brasiliensis Muell. Arg) dan Penentuan Kadar Karet Kering (KKK) dengan Variasi Temperatur Pengovenan di PT. Djambi Waras Jujuhan Kabupaten Bungo, Jambi," Bul. Anat. dan Fisiol., vol. XXII, no. 2, pp. 64-74, 2014. Tersedia: http://eprints.undip.ac.id/44499/. [Diakses: 28-Oktober-2019]

[2] T. K. Waluyo, I. Wahyudi, and G. Santosa, "PENGARUH METODE DAN ARAH SADAP TERHADAP PRODUKSI GETAH ( The Effects of Method and Direction of Tapping on Gum Production from Industrial Plantation Forest $\mathfrak{a ̂}^{\mathrm{TM}} \mathrm{s}$ Jelutong Trees )," J. Penelit. Has. Hutan, vol. 30, no. August 2017, pp. 301-313, 2012. Tersedia: http://ejournal.forda-mof.org/ejournallitbang/index.php/JPHH/article/view/675. [Diakses: 28- Oktober-2019]

[3] D. Jayanti, S. Iriani, and U. Surakarta, "Sistem Informasi Penggajian Pada CV . Blumbang Sejati Pacitan," J. Speed - Sentra Penelit. Eng. dan Edukasi, vol. 6, no. 3, pp. 36-43, 2014. Tersedia: http://ijns.org/journal/index.php/speed/article/view/1041. [Diakses: 28- Oktober-2019]

[4] B. Sadewo and H. Irawan, "ANALISIS DAN DESAIN SISTEM INFORMASI ADMINISTRASI PEMBAYARAN UPAH DAN LEMBUR PEGAWAI BERBASIS 
DESKTOP DENGAN MENGGUNAKAN UML STUDI KASUS : PT . CATUR MITRA TARUMA," J. IDEALIS, vol. 1, no. 2, pp. 222-227, 2019. Tersedia: http://jom.fti.budiluhur.ac.id/index.php/IDEALIS/article/view/1399. [Diakses: 28Oktober-2019]

[5] R. R. W. Jermias, "ANALISA SISTEM INFORMASI AKUNTANSI GAJI DAN UPAH PADA PT. BANK SINARMAS Tbk. MANADO,” J. EMBA, vol. 4, no. 2, pp. 814-828, 2016.

Tersedia: https://ejournal.unsrat.ac.id/index.php/emba/article/view/13180. [Diakses: 28Oktober-2019]

[6] T. Sutabri, Analisis Sistem Informasi. Yogyakarta: Andi, 2012.

[7] M. Kabuhung, "SISTEM INFORMASI AKUNTANSI PENERIMAAN DAN PENGELUARAN KAS UNTUK PERENCANAAN DAN PENGENDALIAN KEUANGAN PADA ORGANISASI NIRLABA KEAGAMAAN," EMBA, vol. 1, no. 3, $\quad$ pp. 339-348, $2013 . \quad$ Tersedia: https://ejournal.unsrat.ac.id/index.php/emba/article/view/1832. [Diakses: 30Oktober-2019]

[8] D. H. P. Purba, "SISTEM INFORMASI AKUNTANSI PENGGAJIAN DAN PENGUPAHAN: STUDI KASUS PADA SEBUAH RUMAH SAKIT," J. Manaj., vol. 4, no. 1, pp. 15-22, 2018. Tersedia: http://ejournal.Imiimedan.net/index.php/jm/article/view/26. [Diakses: 28- Oktober2019]

[9] G. W. Sasmito, "Penerapan Metode Waterfall Pada Desain Sistem Informasi Geografis Industri Kabupaten Tegal," J. Inform. Pengemb. IT, vol. 2, no. 1, pp. 6-12, 2017.

Tersedia: https://ejournal.poltektegal.ac.id/index.php/informatika/article/view/435. [Diakses: 30- Oktober-2019]

[10] R. . Pressman, Rekayasa Perangkat Lunak:Pendekatan Praktisi Buku I. Yogyakarta: Andi, 2015.

[11] A. Nugroho, Rekayasa Perangkat Lunak Berbasis Objek dengan Metode USDP. Yogyakarta: Andi, 2010. 